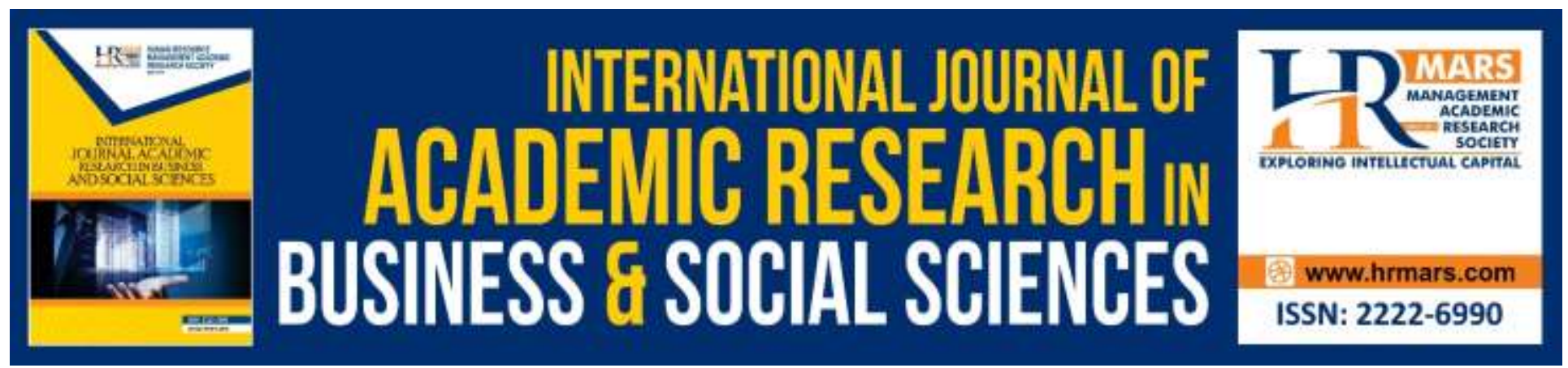

\title{
Educators' Conception of Student Assessment and Their Practices in an Institution of Education in MARA
}

\author{
Maslina Binti Mohamad Mustafa, Umi Kalthom Abdul Manaf
}

To Link this Article: http://dx.doi.org/10.6007/IJARBSS/v9-i10/6492

DOI: $10.6007 /$ IJARBSS/v9-i10/6492

Received: 10 September 2019, Revised: 30 September 2019, Accepted: 05 Oct 2019

Published Online: 24 Oct 2019

In-Text Citation: (Mustafa \& Manaf, 2019)

To Cite this Article: Mustafa, M. B. M., \& Manaf, U. K. A. (2019). Educators' Conception of Student Assessment and Their Practices in an Institution of Education in MARA. International Journal of Academic Research in Business and Social Sciences, 9(10), 292-300.

Copyright: (C) 2019 The Author(s)

Published by Human Resource Management Academic Research Society (www.hrmars.com)

This article is published under the Creative Commons Attribution (CC BY 4.0) license. Anyone may reproduce, distribute, translate and create derivative works of this article (for both commercial and non-commercial purposes), subject to full attribution to the original publication and authors. The full terms of this license may be seen

at: http://creativecommons.org/licences/by/4.0/legalcode

Vol. 9, No. 10, 2019, Pg. 292 - 300

http://hrmars.com/index.php/pages/detail/IJARBSS

JOURNAL HOMEPAGE

Full Terms \& Conditions of access and use can be found at http://hrmars.com/index.php/pages/detail/publication-ethics 


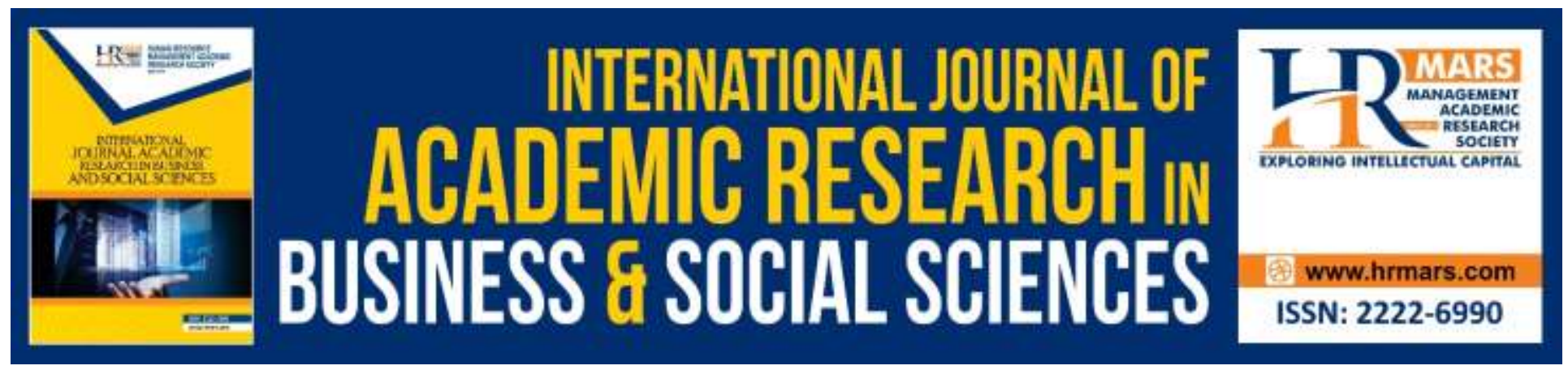

\title{
Educators' Conception of Student Assessment and Their Practices in an Institution of Education in MARA
}

\author{
Maslina Binti Mohamad Mustafa, Umi Kalthom Abdul Manaf \\ Faculty of Educational Studies, Universiti Putra Malaysia
}

\begin{abstract}
Despite existing research on the educators' conception of student assessment, few studies have attempted to explore this topic among tertiary education system in Malaysia. In response to this gap, this is a concept paper aimed to explore educators' conception of student assessment and their practices among MARA Professional College lecturers' $(N=50)$. Descriptive quantitative method will be used to investigate the lecturers' conception of student assessment regarding improvement, school accountability, student accountability and irrelevance as well as the relations between different conceptions purposes and their assessment practices. Acquiring further knowledge on assessment will have profound effect on the teachers' assessment practice. Related organizations should work together in improving the training related to assessment.
\end{abstract}

Keywords: Assessment, Conception of Assessment, Assessment Literacy

\section{Introduction}

Assessment is one of the most crucial part in teaching and learning process. It has always been inseparable part of education system. Throughout the educational process, students are regularly assessed by the educators. According to Opre (2015), Assessment serves the educational system inform of providing information about students' learning process, teachers' teaching activity and the program and institutional accountability. Assessment have an enormous impact on the learners' learning process.

In educational system, assessment perform various function and purposes. Assessment help to provide information about student learning and progress, teaching effectiveness, and program or institutional accountability. Assessment also used to gather all the information needed as the basis in making educational decision (Fenton, 1996). Educators also have the tendency to use assessment along their teaching process as an indicator to decide learner's successes of learning and failure (Erwin, 1991). 
Through the information provided by assessment, educators and learners can adjust and improve their teaching and learning process. Educators can experiment with their pedagogical method and get feedback on the effectiveness of the new method through assessment. Educators able to adjust their teaching method accordingly while the students able to have a different look into their learning (Yetkin, 2017).

According to Danielson (2008) assessment is one of the key for the creation of education based policies. Assessment is used to determine how well the students learning process is happening and at the same time provide the information needed about the format of the curriculum that can lead to the improvement of the educational instruction and settings.

Knowledge regarding assessment work as a basis for the conception of assessment. Theory of assessment, goal of assessment, and the content of the assessment work is crucial in constructing the educators' conception of assessment. Through the collection of knowledge of assessment, educators' conception of assessment is then will be constructed as the ground belief of the nature of the assessment.

This conception help educator's to plan, monitor and evaluate the students' learning process. It influences the educators' teaching practices. Material selection, classroom activities selection, monitoring and assessing students' learning, providing feedback, improving teaching process and many others. The study of educators' conception of assessment is the part of process to understand how educators translate their conception into their work.

\section{Conceptions of Assessment}

Conception are being referred as integration of unitary construct knowledge and beliefs, beliefs representing a subcategory of the conceptions (Opre, 2015). Thompson (1992), define conception as "general mental structure, encompassing beliefs, meanings, concepts, propositions, rules, mental images, preferences, and the like". These contexts have been one of the most perceived in the area of study related to conception in teaching and learning. Brown (2004, 2006, and 2008) have used the term of teachers' conception in investigating the teachers' belief regarding assessment. Opre (2015) also stated in the study regarding teachers' belief in relation to assessment, the establish term used is conception.

The study of teachers' conception of assessment have become a great interest among the researchers. The researchers used to focus on the studies related to teachers' conception regarding teaching process, curriculum development and learning, now the focus has shifted to investigating teachers' conception on assessment (Ravitch, 2011; Darling-Hammond, 2014). This change of paradigm helps to improve the understanding of teachers' belief on assessment and it impact towards educational system (Opre, 2015).

Despite the differences that arise in the educator's conception of assessment, it is undisputable that it plays a very important role in the education system. Ample of research and theory related 
to teachers' beliefs has established that teachers' beliefs about their professional tasks which include assessment, instruction etc. influence the ways that they engage in their work (Barnes, Fives, \& Dacey, 2015; Fives \& Buehl, 2012). Hence it can be concluded that teachers' conceptions is one of the key factor, and also an essential determinants in the teaching and learning process (Opre, 2015).

Educator's perception of assessment in a way influence their pedagogical framework and also effects the student's learning experience. They way teachers conceive of assessment shape and result, will then frame their selection and development of assessment tools in their classrooms (Brown, 2008). This will then influence the way teachers construct their pedagogical framework and approaches. Hence, the study of educator's conception of assessment bring important contribution to the way in which educators understand assessment and how these beliefs influence their teaching method.

There have been many different perceptions mentioned for the assessment. Four main conception of assessment were emphasized by scholars (Brown, 2006 \& 2008; Barnes, Fives, \& Dacey, 2015 \& 2017) which include;

(1) Assessment improves learning and teaching.

(2) Assessment makes students accountable for learning.

(3) Assessment demonstrate the quality of schools.

(4) Assessment should be rejected because it is invalid, irrelevant and negative.

According to these basic conception, Brown $(2004,2006)$ developed and used the Conception of Assessment (COA-III) instrument to assess teachers' conceptions of the nature of assessment. Brown based the COA-III on the extant literature to describe the purposes of assessment, which is that assessment is used to improve teaching and learning, makes students accountable for their learning, and demonstrate the quality of school. Extending from these three conceptions for the purpose of assessment, Brown $(2004,2006)$ suggested that the fourth conception of assessment should be rejected as it is irrelevant. Based on this framework, Brown developed the four-factor COA measure to assess teachers' conceptions of assessment.

The COA-III has been widely used to examine teacher's conception of assessment. Such research has been done in multiple context. The COA-III has been administered in various country such as New Zealand (Brown, 2006 \& 2008), Hong Kong (Brown et al, 2009), United States (Barnes, Fives, \& Dacey, 2017; Deneen \& Brown 2016) and Iran (Moiinvaziri, 2015). The result from these research show that the teachers' conception towards assessment differ from society to society and there is tendency for the conception to be consistent with the policy and cultural priorities.

According to research conducted in New Zealand and Queensland (Brown, 2006 \& 2008), the result shows that teachers have the tendency to identify the improvement of teaching activity and also learning process as their primary purpose in conducting assessment for their students. 
Conception of assessment that focus on the teaching and learning process improvement was positively associated with the increased of learning outcomes (Brown \& Hirschfeld, 2008).

While in Hong Kong, the teachers' conception of assessment lean towards making students accountable of their own learning (Brown, Kennedy, Fok, Chan \& Yu, 2009). The Chinese educational culture is strongly associated with public examinations. This historical and cultural acceptance play a very important role in determining the value of public examinations. Such occurrence clearly impacts the teachers' conception towards assessment.

Research conducted in United States instead suggested that the teachers' conception of assessment put more focus on assessment as valid for accountability (Barnes, Fives, \& Dacey, 2017). As the high-stakes testing movement expands vigorously in the U.S., teachers feel that it may be necessary for them to put more effort in ensuring the accountability of both students and schools.

For the research conducted by Moiinvaziri (2015), the result suggested that most of the teachers believed that the purpose of assessment is to help with teaching and learning improvement. In Iran tertiary educational system the authorities rarely have any direct supervision over the classes, the students or even the reliability and validity of the taken exams. This shown that the results of the examination might not be a good indicator of the level or quality of the university but rather focus on the effectiveness of the teaching activity and learning process.

\section{Problem Statement}

Educators, learners, parents and policy makers all have a shared responsibility in conducting and monitoring assessment practice. The main role in assessment process depends on the educators. Throughout the evolution of assessment in education, educators use variety of assessment method to assess the teaching and learning process. According to Stiggins (1988), classroom assessment requires a large amount of time and effort. Educators have the tendency to spend as much as $40 \%$ of the learning process directly involves in assessment related activities.

According to Moiinvaziri (2015), educators' choice of assessment in assessing their student's performance is based on their beliefs about theories of language, teaching, learning and assessment. Educators' perception of assessment define their choice of assessment. Educators' belief and practices determine their application of assessment techniques (Yetkin, 2017). In ensuring the assessment is being utilized in a more meaningful way, Barnes et al (2015) and Fulmer et al (2015) stated that there is a need for further discussion on educators' perception of assessment and their assessment practice. Hence, it is crucial to explore the educators' conception of assessment.

Even though, there is an increasing amount of studies surrounding the educators' conception of assessment and their assessment practice are being conducted recently, in multiple international and diverse cultural contexts but a few of them have been carried out in Malaysia especially for 
INTERNATIONAL JOURNAL OF ACADEMIC RESEARCH IN BUSINESS AND SOCIAL SCIENCES

Vol. 9, No. 10, October, 2019, E-ISSN: 2222-6990 @ 2019 HRMARS

tertiary education level. Therefore, an exploration on lecturers' conception of assessment in this context will help to reveal beliefs and assessment practices as well as contribute to literature.

\section{Research Objectives}

The objectives for this research are:

1. To investigate the lecturers' conception of assessment.

2. To determine the most frequently used assessment method.

3. To study the relationship between lecturers' conception of assessment and their choice of assessment method.

\section{Methodology \\ Research Design}

For this study, a descriptive quantitative method will be used to investigate the lecturers' perception of student assessment regarding improvement, school accountability, student accountability and irrelevance as well as the relations between different perceptions purposes and their assessment practices.

A survey will be conducted to collect the data regarding the educator's conceptions about the assessment and their assessment method preference. A TCOA - IIIA Abridged scale will be utilized in this study. This instrument consists of 27 items which is divided according to the conception of assessment. This is the shorter version of original "Teacher Conception of Assessment" inventory that was developed and used by Brown $(2001,2003)$.

\section{Sampling}

For this research, convenience sampling method will be used. Through non-probability sampling technique, subjects are selected based on their convenience accessibility and proximity to the researcher. Participants will include lecturers from six MARA Professional Colleges (KPM) branches. These six branches are KPM Seri Iskandar, KPM Beranang, KPM Bandar Melaka, KPM Ayer Molek, KPM Indera Mahkota and KPM Bandar Penawar. All these KPM are located in Peninsular Malaysia. The age range for the lecturers in KPM is in between 24 to 60 years old. Participants taught a range of grade levels and subject areas. Participants' educational level vary from degree, master's degree and doctoral degree with different years of teaching experiences.

\section{Data Collection Instrument}

The data will be gathered through an instrument adapted from the "Teacher Conceptions of Assessment Abridged Scale" (TCOA - IIIA Abridged Scale). This instrument is the shorter version of Teacher Conceptions of Assessment Scale which was originally developed and used in English by Brown (2001 - 2003). There is a total of 27 items in this scale where 6-point rating scale that is degreed from 1 (Strongly Disagree) to 6 (Strongly Agree) is used. Teacher Conceptions of Assessment Abridged Scale" (TCOA - IIIA Abridged Scale) includes 4 conception levels. These conceptions are improvement conception (12 items), school accountability (3 items), student accountability ( 3 items) and finally irrelevance conception ( 9 items). 


\section{Data Analysis}

Descriptive statistics and point-biseral correlation will be used to analyze participants' answers. Descriptive statistics allows to synthetize and represent the information available in a data set, such as the one collected with the questionnaire. Tables and graphs will constructed and statistical measures will be computed. The participants' conception of assessment and their choice of assessment will be analyzed and the statistical data will be represented in form of number and percentage of the answers, mean, median and standard deviation.

The relationship between the participants' conception of assessment and their choice of assessment method will then be analyzed by using point-biseral correlation. A point-biserial correlation is used to measure the strength and direction of the association that exists between one continuous variable and one dichotomous variable. The analyzed data will be represented in form of correlation table. The table presents the point-biserial correlation coefficient, the significance value and the sample size that the calculation is based on.

\section{Conclusion}

Some teachers might not be fully aware of different issues that arise in assessment. Since teachers' beliefs towards assessment and their methods of assessment could have a profound effect on their professional development as well as students' learning (Tillema, 2009), acquiring further knowledge and training in this regard seems necessary.

It is anticipated that assessment should be used for improvement of teaching and learning and irrelevant view of assessment is the least agreed conception when it comes to assessment. The conception of assessment should be used for improvement of teaching and learning lead to the practice of summative assessments as the main source of data for improvement of teaching and learning. The usage of diverse assessment method such as diagnostic test help educators to assess the teaching and learning process.

There is a few of limitation for this particular studies like the study will only be conducted in one educational organization and does not include the population from west coast of Malaysia, which might lead to limited number of participants. Another limitation that might arise from this study is that the inventory presented by Brown (2006) might not be suitable in the context of Malaysian educators and might not represent their conception of assessment.

A more extensive participant should be arranged in order to ensure that the data collected regarding Malaysian teachers conception of assessment is more thorough and precise. An attempt to understand teachers' perceptions, knowledge, readiness and responses to any planned reform particularly on assessment should be conducted to ensure optimal effectiveness of the educational system. 
In this way, organizations that train teachers and also those that involve in designing the curriculum can make necessary adjustment in the methods and materials that will be used as a part of the teachers' training program. More focus should be put on giving exposure to the teachers in terms of theoretical and practical knowledge of assessment. It is hoped that this study can contribute in the development of educational system in Malaysia especially in terms of assessment.

\section{Corresponding Author}

Umi Kalthom Abdul Manaf senior lecturer at the Faculty of Educational Studies, Universiti Putra Malaysia, 43400 UPM Serdang, Selangor Darul Ehsan, Malaysia. Email: umizat90@upm.edu.my

\section{References}

Azis, A. (2015). Conceptions and practices of assessment: A case of teachers representing improvement conception. TEFLIN Journal - A Publication on the Teaching and Learning of English, 26(2), 129. doi:10.15639/teflinjournal.v26i2/129-154

Barnes, N., Fives, H., \& Dacey, C. M. (2015). Teachers' beliefs about assessment. In H. Fives \& M. G. Gill (Eds.), International handbook of research on teacher beliefs (pp. 284-300). Routledge.

Barnes, N., Fives, H., \& Dacey, C. M. (2017). U.S. teachers' conceptions of the purposes of assessment. Teaching and Teacher Education, 65, 107-116. doi:10.1016/j.tate.2017.02.017

Brown, G. T. L. (2004). Teachers' conceptions of assessment: Implications for policy and professional development. Assessment in Education: Principles, Policy \& Practice, 11, 301318.doi:10.1080/0969594042000304609

Brown, G. T. L. (2006). Teachers' conceptions of assessment: Validation of an abridged instrument. Psychological Reports, 99, 166-170.

Brown, G. T. L. (2008). Conceptions of assessment: Understanding what assessment means to teachers and students. Nova Science Publishers.

Brown, G. T. L., \& Hirschfeld, G. H. F. (2008). Students' conceptions of assessment: Links to outcomes. Assessment in Education: Principles, Policy \& Practice, 15(1), 3-17. doi:10.1080/09695940701876003

Brown, G. T. L., Kennedy, K. J., Fok, P. K., Chan, J. K. S., \& Yu, W. M. (2009). Assessment for student improvement: Understanding Hong Kong teachers' conceptions and practices of assessment. Assessment in Education: Principles, Policy \& Practice, 16(3), 347-363. doi: 10.1080/09695940903319737

Danielson, C. (2008). Assessment for learning: For teachers as well as students. In C. A. Dwyer (Ed.), The future of assessment: Shaping teaching and learning (pp. 191-213). Taylor \& Francis.

Darling-Hammond, L. (2014). Next generation assessment: Moving beyond the bubble test to support 21st century learning. John Wiley \& Sons.

Deneen, C. C., \& Brown, G. T. (2016). The impact of conceptions of assessment on assessment literacy in a teacher education program. Cogent Education, 3(1).

doi:10.1080/2331186x.2016.1225380 
Erwin, T. D. (1991). Assessing student learning and development: A guide to the principles, goals, and methods of determining college outcomes. Jossey-Bass.

Fenton, R. (1996). Performance assessment system development. Alaska Educational Research Journal, 2(1), 13-22.

Fives, H., \& Buehl, M. (2012). Spring Cleaning for the "messy" construct of teachers' beliefs: What are they? Which have been examined? What can they tell us? In K. R. Harris, S. Graham, \& T. Urdan (Eds.), APA educational psychology handbook: Volume 2 individual differences and cultural and contextual factors (pp. 471-499). American Psychological Association.

Fulmer, G. W., Lee, I. C. H., \& Tan, K. H. K. (2015). Multi-level model of contextual factors and teachers' assessment practices: An integrative review of research. Assessment in Education: Principles, Policy, and Practice, 22, 475-494. doi:10.1080/0969594X.2015.1017445

Moiinvaziri, M. (2015). University teachers' conception of assessment: A structural equation modeling approach. American Institute of Science, 1(3), 75-85.

Opre, D. (2015). Teachers' conceptions of assessment. Procedia-Social and Behavioral Sciences, 209, 229-233. doi:10.1016/j.sbspro.2015.11.222

Ravitch, D. (2011). The death and life of the great American school system: How testing and choice are undermining education. Basic Books.

Stiggins, R. J. (1988). Revitalizing classroom assessment: The highest instructional priority. Phi Delta Kappan, 69(5), 363-368.

Thompson, A. (1992). Teachers' beliefs and conceptions: A synthesis of the research. In D. Grouws (Ed.), Handbook of research on mathematics teaching and learning (pp. 127-146). Macmillan.

Tillema, H. H. (2009). Assessment for learning to teach: Appraisal of practice teaching lessons by mentors, supervisors, and student teachers. Journal of Teacher Education, 60(2), 155-167.

Yetkin, R. (2017). Pre-service English teachers' conception of assessment and their future assessment practices in a Turkish context (Unpublished master's thesis). Hacettepe University. Retrieved February 13, 2018, from http://www.openaccess.hacettepe.edu.tr:8080/xmlui/handle/11655/3909 